\title{
Prospective study of the human polyomaviruses BK and JC and cytomegalovirus in renal transplant recipients
}

\author{
SD GARDNER, ${ }^{*}$ EFD MACKENZIE, $\dagger$ C SMITH, $\dagger$ AA PORTER* \\ From the *Virus Reference Laboratory, Central Public Health Laboratory, Colindale Avenue, London \\ NW9 5HT, and the †Department of Pathology, Southmead General Hospital, Westbury on Trym, Bristol \\ BS10 5NB
}

SUMMARY Forty eight renal transplant recipients were investigated prospectively for evidence of infection with the polyomaviruses $\mathrm{BK}$ and $\mathrm{JC}$ and cytomegalovirus. An active polyomavirus infection was shown in 31 patients $(65 \%)$ and cytomegalovirus in $30(62.5 \%)$. Half of the BK and $\mathrm{JC}$ virus infections occurred within the first three months after transplantation compared with $93 \%$ of the cytomegalovirus infections. Very late polyomavirus infections two or more years after the transplant were also shown.

Cytology was useful in identifying polyomavirus but not cytomegalovirus infections, and 21 $(68 \%)$. of the 31 polyomavirus infected patients excreted inclusion-bearing cells.

Only three patients had symptoms possibly associated with the polyomavirus infection. One patient with BK virus infection developed ureteric stenosis and a second patient had malaise and vomiting. One patient with $\mathrm{JC}$ virus infection developed pericarditis and effusion. Renal function became impaired at the time of the polyomavius infection in eight patients $(26 \%)$ and ureteric obstruction and pericarditis developed in two patients treated with methyl prednisolone for possible rejection. At the end of the study 25 of the 31 polyomavirus infected patients $(81 \%)$ had functioning renal grafts.

The detection of polyomavirus infection is important as increased immunosuppression needs to be avoided to prevent possible complications such as ureteric stenosis in transplant recipients.

Viral infections in renal transplant recipients have been well documented as occurring in the posttransplant period. In particular, infections with cytomegalovirus and herpes simplex and varicella zoster viruses can cause serious problems. It has been unclear whether these infections initiate rejection episodes or have an adverse effect on renal function and graft survival. Recent studies have suggested that patients with cytomegalovirus infection and an associated viraemia may have circulating immune complexes which deposit in the kidney causing glomerulitis and deterioration of renal function. ${ }^{1}$

Investigations have been done by various workers in an attempt to relate the time of onset of viral infection to the transplant operation and also to determine whether the infection is due to reacti-

Accepted for publication 25 January 1984 vated latent virus or arises from exogenous infections introduced via the donor kidney or blood. Warrell and her colleagues ${ }^{2}$ showed in a prospective study that most primary infections with cytomegalovirus occurred within the first two months after grafting and that the likely source of these infections was the donor kidney. Secondary infection in the seropositive patients occurred independently of the antibody status of the kidney donor.

In 1971 a new virus, a human polyomavirus, was isolated from the urine of a renal transplant recipient and named BK virus (the initials of the patient). ${ }^{3}$ Subsequent work in England with BK virus showed that $70 \%$ of renal transplant recipients were seropositive at the time of the transplant operation and that just over half of them had serological evidence of an active infection after transplant. ${ }^{4}$ In the original patient BK and in four other patients in 
a later investigation, this infection was associated with ureteric stenosis and recognised because of the large number of inclusion-bearing cells seen in the urine..$^{56}$

An antigenically distinct but similar polyomavirus, JC virus, was also isolated in 1971 from the brain of a patient with Hodgkin's disease and the rare demyelinating disease progressive multifocal leucoencephalopathy (PML). ${ }^{7} \quad$ PML is uncommon and is seen as a late complication in patients with altered immunity subsequent to diseases such as chronic lymphocytic leukaemia, Hodgkin's disease, lymphosarcoma and sarcoidosis. Ten cases of PML have been reported in renal transplant recipients. $^{8-10} \mathrm{JC}$ virus has been identified in 44 cases of PML and is considered the main agent of this disease. " Silent infection with JC virus is common in children and adults, unassociated with any neurological disease, and the virus has been found in the urine of renal transplant recipients ${ }^{1213}$ and also pregnant women. ${ }^{14}$

A prospective study of renal transplant recipients was started in 1977 in an attempt to determine: (a) whether primary or secondary infections with BK and $\mathrm{JC}$ viruses were associated with any clinical illness or effect on renal function; and (b) the time of these infections in relation to the transplant operation. The patients were also studied for evidence of cytomegalovirus infection in order to be able to eliminate any possible effects due to this virus.

\section{Material and methods}

\section{STUDY GROUP}

During the three year period from December 1977 until September 1980, 65 patients received kidney transplants and initially entered the study. Thirteen of them, however, suffered acute rejection and transplant nephrectomy within four weeks of the transplant operation; three patients died within the same period; and one patient returned to Greece and was not followed further. These 17 patients were excluded from the investigation.

The study group therefore consisted of 48 patients, with a mean age of 37 years (range 11-55 years). Twenty nine patients were male and 19 female. Forty four patients were recipients of a first kidney transplant and four were recipients of a second graft. Only two patients were given kidneys from living related donors, whereas 46 received cadaver kidneys. Serial serum samples were obtained from all patients. These were taken immediately before the transplant operation, twice weekly during the first few weeks, then at increasing intervals of two weeks, one month, and three months, depending on when they attended the outpatients department or were readmitted to hospital. Urine samples for cytological examination were obtained as described below. The patients were followed from two to 46 months (mean period 23 months).

A flow sheet was kept on each patient by the renal physicians. Information relating to temperature, white cell count, renal function, blood glucose concentration, immunosuppressive therapy, and complications was extracted from the data available to the authors, and this was correlated with antibody response and virus excretion.

\section{IMMUNOSUPPRESSION}

The transplant operations were done by two surgeons who used different regimens for immunosuppression. All the patients received $2 \mathrm{mg} / \mathrm{kg}$ azathioprine daily. Patients operated on by surgeon A were given $300 \mathrm{mg}$ of hydrocortisone and $60 \mathrm{mg}$ of prednisolone on day 1 after the operation and $100 \mathrm{mg}$ of hydrocortisone and $60 \mathrm{mg}$ prednisolone on day 2 . Thereafter they were given 30 $60 \mathrm{mg}$ of prednisolone daily with a total dose of $630 \mathrm{mg}$ given during the first 14 postoperative days. Surgeon B's patients received $30-200 \mathrm{mg}$ prednisolone daily with a total dose of $1140 \mathrm{mg}$ prednisolone given during the first two weeks. Methyl prednisolone (Solu-Medrone) was used by both surgeons to treat rejection episodes.

\section{CYTOLOGICAL INVESTIGATIONS}

Specimens of urine were collected from patients after transplantation on a daily basis in the postoperative period and thereafter at every readmission to hospital and outpatient visit. They were screened for evidence of rejection and the presence of inclusion-bearing cells associated with virus infection. The specimens were processed in the laboratory using a cytocentrifuge and three slides were obtained, two stained with Papanicolaou and one with methyl green pyronine, the latter being used to identify pyronine positive lymphocytes. Where inclusion-bearing cells were identified further specimens of urine and serum were sent to Colindale for virus isolation and antibody studies.

\section{VIROLOGICAL INVESTIGATIONS \\ Serology}

Antibody to $\mathrm{BK}$ and $\mathrm{JC}$ viruses was studied by means of a haemagglutination inhibition test. A microtechnique was employed using 16 units of each viral antigen. ${ }^{14}$ Serum samples were considered positive if a haemagglutination inhibition titre of 20 or more was found. IgM antibodies against BK and JC viruses were measured by haemagglutination inhibi- 
tion after serum samples were fractionated on sucrose density gradients.

An eight fold or greater rise in IgG antibody was considered evidence of infection and this was confirmed when possible by the demonstration of polyomavirus particles in the urine by electron microscopy or isolation of virus, or both.

Antibody to cytomegalovirus was determined by a complement fixation test using the Rawles strain of cytomegalovirus. Only patients with antibody titres of $<2$ were considered seronegative and susceptible to a primary infection.

\section{Electron microscopy}

Selected urine samples were examined by electron microscopy. Three millilitre volumes were centrifuged at $20000 \mathrm{rpm}$ for $1 \mathrm{~h}$ and the resulting pellets were diluted in distilled water, mixed with $0.05 \%$ bovine plasma albumin, and negatively stained with $3 \%$ phosphotungstic acid at $\mathrm{pH} 6 \cdot 3$. A drop was applied to a 400 mesh formvar-carboncoated grid and examined at a magnification of $\times 60000$ in an AEI EM 6B electron microscope.

\section{Virus isolation}

The urine samples were inoculated into human fetal brain cells, human embryo kidney cells, and human embryo lung fibroblast cells for the isolation of JC virus, BK virus, and cytomegalovirus respectively as described previously. ${ }^{14} \mathrm{~A}$ minimum total incubation time of three months was achieved before cultures were considered negative for $\mathrm{BK}$ and $\mathrm{JC}$ viruses. The polyomaviruses were identified by the haemagglutination inhibition method using specific antisera.

\section{Results}

\section{CYTOLOGY}

During the study 3497 urine specimens were examined cytologically and inclusion-bearing cells were seen in $327(9 \%)$. Twenty one $(44 \%)$ of the 48 patients were identified as excretors.

The inclusion-bearing cells were easily identified in the cytological preparations. Invariably they were larger than normal urothelial cells. The nuclei were mainly of three types; those with an opaque ground glass appearance; those with only the nuclear border of condensed chromatin remaining; and, rarely, those with the classic "owl's eye" appearance with the hyperchromatic inclusion centrally placed.

\section{VIROLOGY}

An active polyomavirus infection, diagnosed serologically or by electron microscopy or virus isolation, or both, was present in $31(65 \%)$ of the 48 renal transplant recipients. Twenty one patients were infected with BK virus, 17 with $\mathrm{JC}$ virus, and seven of them apparently had infections with both.

\section{$B K$ virus}

Nine hundred and six serum samples from the 48 patients were tested for BK virus antibody. Only six of the 48 patients $(12 \%)$ were seronegative before the transplant operation (Table 1). Two of the six developed BK virus antibody after the operation (titres 1280 and 20480 ), but only one was confirmed as a primary infection. BK virus was isolated from the urine of this patient six weeks after transplantation, when the antibody titre was less than 10 . Two weeks later the antibody level was 20480 . BK virus was not isolated from subsequent urines. The second patient may have been responding anamnestically to a concurrent primary infection with $\mathrm{JC}$ virus or could have had a double infection (Fig. 1). Details of this patient (patient B) are given later.

Nineteen of the 42 seropositive patients $(45 \%)$ had eight fold or greater increases in BK virus antibody titre and experienced secondary infection (Table 1). The antibody rise was substantial ( 32 fold or more) in 17 patients. Seven of the 19 patients also had rises in JC virus antibody but in three this may have been an anamnestic response.

Urine samples were examined from 14 of the 19 patients and infection was confirmed in eight. Polyomavirus particles were seen in the urine of seven patients and BK virus was isolated from five and JC virus from one. One other patient was excreting $\mathrm{BK}$ virus.

Thirteen urine samples were examined from the six patients excreting BK virus. The virus was present in the urine between five and eight weeks after the transplant operation in four of the six excretors; between 12 and 17 weeks in one; and at 34 weeks in another. In all six patients BK virus was first isolated at a time when the BK virus antibody titre was low. Subsequently there was a greater than 100 fold

Table 1 Serological findings in $\mathbf{4 8}$ renal transplant recipients

\begin{tabular}{lccc}
\hline & $B K$ virus & JC virus & $C M V$ \\
\hline $\begin{array}{l}\text { Number of patients } \\
\text { seronegative before } \\
\text { transplantation }\end{array}$ & $6(12 \%)$ & $22(46 \%)$ & $19(40 \%)$ \\
$\begin{array}{l}\text { Number of seronegative } \\
\text { patients with } \\
\text { primary infection }\end{array}$ & $2(33 \%)$ & $5(23 \%)$ & $6(32 \%)$ \\
$\begin{array}{l}\text { Number of seropositive } \\
\text { patients with secondary } \\
\text { infection }\end{array}$ & $19(45 \%)$ & $12(46 \%)$ & $24(83 \%)$ \\
$\begin{array}{l}\text { Number of seropositive } \\
\text { patients with stable titres or a } \\
\text { fall in antibody }\end{array}$ & $23(55 \%)$ & $14(54 \%)$ & $5(17 \%)$ \\
\hline CMV = cytomegalovirus. & & &
\end{tabular}




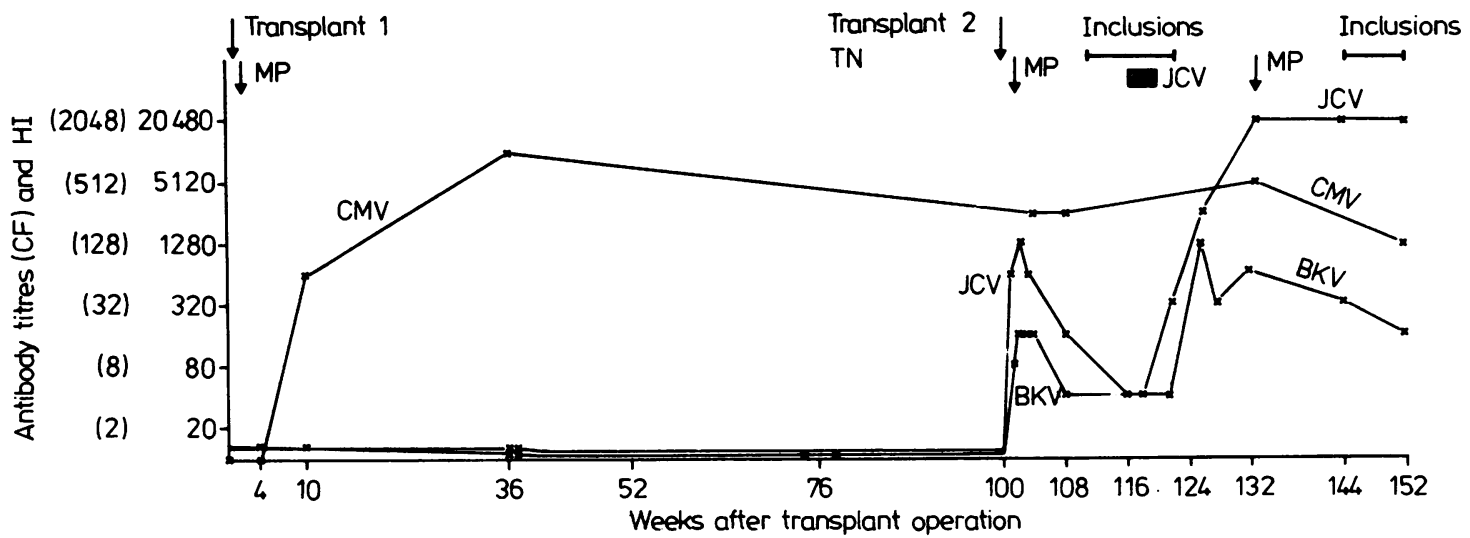

Fig. 1 Patient B. Serological response to polyomavirus $B K$ and $J C(H I)$ and cytomegalovirus (CF) after two renal transplant operations and treatment with methyl prednisolone (MP). HI = haemagglutination inhibition; $C F=$ complement fixation. $T N=$ transplant nephrectomy.

Table $2 B K$ virus infection related to time of the renal transplant operation and clinical response

\begin{tabular}{|c|c|c|c|c|c|}
\hline $\begin{array}{l}\text { Type of } \\
\text { infection }\end{array}$ & $\begin{array}{l}\text { Time relative } \\
\text { to transplant }\end{array}$ & $\begin{array}{l}\text { No of } \\
\text { cases }\end{array}$ & $\begin{array}{l}\text { Clinical features } \\
\text { (no. of patients) }\end{array}$ & & $\begin{array}{l}\text { Other virus infection } \\
\text { during same period }\end{array}$ \\
\hline $\begin{array}{l}\text { Primary ( } 2 \text { patients) } \\
\text { Secondary ( } 19 \text { patients) }\end{array}$ & $\left.\begin{array}{r}3-5 \text { months } \\
8 \text { months } \\
11 \text { months } \\
24 \text { months } \\
17 \text { months }\end{array}\right\}$ & $\begin{array}{l}1 \\
1 \\
9(47 \%)\end{array}$ & $\begin{array}{l}\text { Pyrexia } \\
\text { None } \\
\text { Pyrexia } \\
\text { Pyrexia, respiratory } \\
\text { Ureteric obstruction } \\
\text { Pyrexia, malaise, vomiting } \\
\text { None } \\
\text { None } \\
\text { None } \\
\\
\text { Pyrexia, influenza-like } \\
\text { illness, respiratory }\end{array}$ & $\begin{array}{l}\text { (2) } \\
\text { (1) } \\
(1) \\
(4) \\
(6) \\
(3)\end{array}$ & $\begin{array}{l}\text { JC virus } \\
\text { CMV } \\
\text { CMV } \\
\text { CMV } \\
- \\
- \\
-\end{array}$ \\
\hline
\end{tabular}

CMV = cytomegalovirus.

increase and this high level of antibody was maintained thereafter.

The patient infected with JC virus excreted virus intermittently from 14 months to three years after the transplant operation. An increase in antibody was not shown before two years, however, when there was a gradual slight increase in antibody (eight fold) to both JC and BK viruses.

The secondary infection was not confirmed in six patients either by electron microscopy or virus isolation: the urines were not collected at the optimum time in four of them.

Just under half $(42 \%)$ of the study group had active infections with $\mathrm{BK}$ virus after transplantation and 16 of the 21 patients had inclusion-bearing cells in the urine.

Time of the $B K$ virus infection related to the transplant operation and the clinical response The definite primary BK virus infection occurred six weeks after the transplant operation and nearly half of the 19 secondary infections occurred between five and eight weeks. Of the remaining 10 secondary

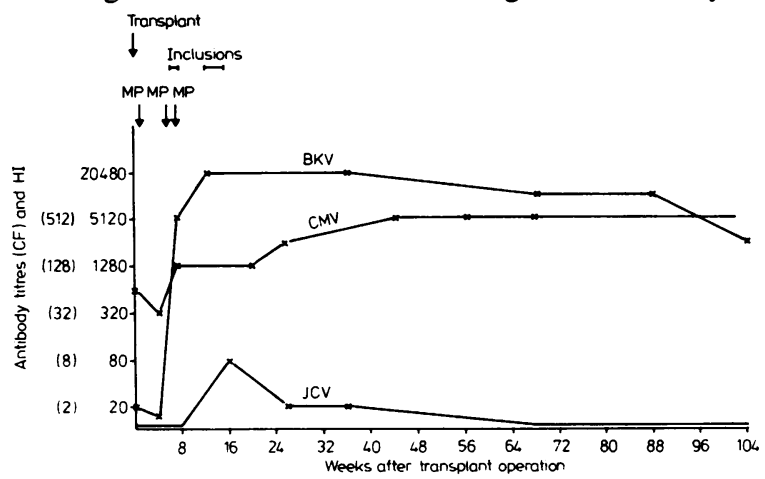

Fig. 2 Patient F. Serological response to polyomavirus $B K$ and $\mathrm{JC}(\mathrm{HI})$ and cytomegalovirus $(\mathrm{CF})$ after a renal transplant operation and treatment with methyl prednisolone (MP). $\mathrm{HI}=$ haemagglutination inhibition; $C F$ = complement fxation. 
infections six were recognised between three and five months and four were late infections at 8, 11, 17 , and 24 months respectively (Table 2 ). With the exception of one patient (patient F) who developed ureteric stenosis, the clinical features present at the time of the BK virus infection were minimal. No recognisable illness was associated with the primary infection and no symptoms were apparent in 13 of the '19 patients with secondary infections.

Six patients had symptoms temporally related to the BK virus infection. Five of them experienced fever, which in one patient was accompanied by an influenza-like illness and in another by respiratory symtoms. Four of the five patients also had concurrent cytomegalovirus infection, however, which may have accounted for most if not all of the symptoms.

Only two patients therefore may have had a clinical response to the secondary $\mathrm{BK}$ virus infection. One of them experienced fever, malaise, and vomiting in the second month after transplantation and the other, patient $F$, developed ureteric stenosis. Details of the laboratory findings in the latter case are shown in Fig. 2. In 1977 patient $F$ received a first renal transplant and was treated for early rejection at eight days with methyl prednisolone. Five weeks later virus inclusion-bearing cells were seen in the urine. At this time his renal function deteriorated and he was again treated with methyl prednisolone for possible rejection. Excretory urography showed that the donor ureter was partially obstructed and a renal biopsy showed no evidence of acute rejection. In view of this finding and because of the concurrent infection with BK virus, further acute rejection therapy was withheld. The BK virus antibody concentrations rose sharply, the inclusion-bearing cells disappeared from the urine, and his renal function recovered. The patient remained well with a functioning graft four years after the operation. At the same time as the $B K$ virus infection, his cytomegalovirus antibody titre rose from 64 to 512; four weeks later he developed JC virus antibody (Fig. 2), having been previously seronegative. The
JC virus antibody was transient and he eventually reverted to being seronegative, but IgM antibody to both BK and JC viruses was detected after the BK virus infection.

JC virus

Six hundred and fifty one serum samples from the 48 patients were tested for JC virus antibody. Twenty two of the 48 patients $(46 \%)$ had no antibody before the transplant operation and five of the seronegative cases $(23 \%)$ subsequently had primary $\mathrm{JC}$ virus infections (Table 1). The increase in titre was 16 fold in two cases and more than 100 fold in three. Two further patients also seroconverted, but the JC virus antibody was transient and most likely to have been an anamnestic response to BK infection. Urines were examined from four of the five patients with primary infections and polyomavirus particles were seen in two of them by electron microscopy 16 weeks and 10 months after transplantation. JC virus was isolated from the former urine but not from the latter, probably because the virus particles had been coated with antibody.

Twelve of the 26 seropositive patients $(46 \%)$ had eight fold or greater increases in JC virus antibody, suggesting a secondary infection, but six of them also had rises in antibody to $\mathrm{BK}$ virus and in most cases this was the major response. Nevertheless, in two patients known to be excreting BK virus both BK and JC virus specific IgM was present in their serum. It was not possible to be sure in those patients with serological evidence of infection with both viruses whether these were dual infections or anamnestic responses.

Seventeen urine samples were examined from seven of the 12 patients. Polyomavirus particles were seen by electron microscopy in the urine of five patients. JC virus was isolated on two occasions from one of them at 14 months and 31 months after transplantation and BK virus from three. An unidentified polyomavirus was isolated 16 months after transplantation from the other patient; this

Table $3 J C$ virus infection related to time of the renal transplant operation and clinical response

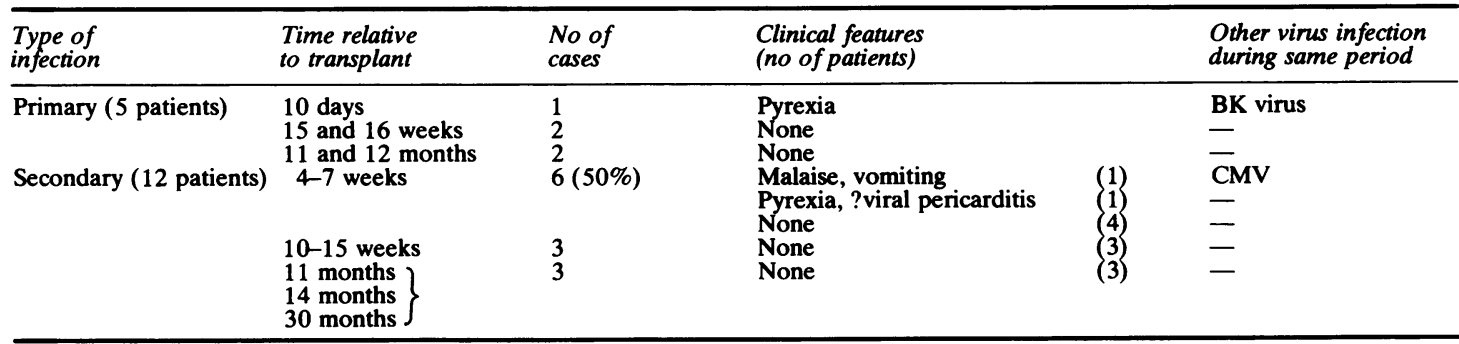

$\mathrm{CMV}=$ cytomegalovirus . 
virus was probably JC virus from its restricted growth pattern in cell culture.

About one third of the transplant recipients studied were infected with JC virus after transplantation and inclusion-bearing cells were found in 13 of these 17 patients.

Time of JC virus infection related to the transplant operation and the clinical response

One of the patients (patient B) with a primary infection with JC virus had evidence of infection 10 days after a second transplant operation (Table 3). Patient $B$, a child of 12 years, had not seroconverted after the first transplant operation and he remained seronegative to both JC and BK viruses for two years (Fig. 1). During this period the original renal disease recurred and renal function deteriorated and he was managed by haemodialysis. He received an increased dose of azathioprine before the second transplant operation and six days after transplantation was given methyl prednisolone because of reduced renal function. At 10 days he had a mild fever and developed antibody to both JC and BK viruses. After two months, antibody to both viruses declined and remained low for the next 10 weeks. During this interval inclusion-bearing cells were present in the urine and JC virus isolated. Eighteen weeks after the operation there was a second substantial rise in antibody titre to both viruses (Fig. 1) and the $\mathrm{JC}$ virus antibody concentrations remained raised until his death 18 months after the second renal transplant. Specific IgM antibodies to both BK and $\mathrm{JC}$ viruses were present and a rise followed by a fall and then subsequent rise was shown similar to the IgG response.

The other four primary infections occurred between 15 and 16 weeks after the operation (two cases) and at 11 and 12 months (Table 3). Apart from a mild fever in one patient there was no illness or symptoms associated with the primary infection.

Six of the 12 secondary JC virus infections occurred between four and seven weeks, three between 10 and 15 weeks, and three were late infections at 11,14 , and 30 months. No symptoms were seen in 10 patients (Table 3). One patient experienced malaise and vomiting but was also infected with cytomegalovirus. Only one patient had symptoms possibly associated with the JC virus infection. This patient had no antibody at the time of a first transplant operation and transplant nephrectomy three months later. When he was given his second transplant 12 months afterwards, however, he had seroconverted and had low levels of JC virus antibody. Twelve weeks after the second transplant he was given methyl prednisolone for deteriorating renal function and subsequently his JC virus anti- body levels increased from 40 to 640 . At this time he developed palpitations and severe chest pain and was admitted as an emergency case to the intensive care unit, where he was found to have a pericardial rub and diagnosed as possibly having a viral pericarditis. Six months later he had a recurrence of symptoms and developed a pericardial effusion. His condition improved and his renal function has remained stable.

\section{Cytomegalovirus}

Thirty $(62.5 \%)$ of the 48 renal transplant recipients experienced an infection with cytomegalovirus after transplantation. Inclusion-bearing cells were not seen in the urine of 17 of these patients. Thirteen patients were excreting such cells but all of them also had concurrent infection with BK and/or JC virus.

\section{Primary infections}

Nineteen of the 48 patients $(40 \%)$ had no cytomegalovirus antibody before the transplant operation. Six (32\%) of these 19 seronegative cases experienced a primary infection (Table 1). Five of the infections occurred between four and seven weeks after transplantation and one was at 10 weeks. Unlike the primary infection with BK and JC viruses all six patients had symptoms related to the cytomegalovirus virus infection and none of them was experiencing a concurrent polyomavirus infection. Three of the six patients were seriously ill with fever and pneumonia, two also had a pancreatitis, and one patient died from the infection. Nevertheless, four of the five surviving patients made a good recovery and had functioning grafts at the end of the study period.

\section{Secondary infections}

Twenty four $(83 \%)$ of the 29 seropositive patients had secondary infections with cytomegalovirus (Table 1). In 17 of the 24 patients (71\%) the infection occurred betweeen four and eight weeks after transplantation. In five it was between nine and 12 weeks, and in only two patients $(8 \%)$ was there a late infection at eight and 17 months.

Thirteen of the patients had symptoms possibly related to the cytomegalovirus infection. Twelve developed fever and in five this was accompanied by respiratory symptoms. One patient had malaise and vomiting. Although six of the 13 patients also had concurrent infection with a polyomavirus it was thought unlikely that this virus was responsible for the symptoms encountered. 
$B K$ and JC virus infection related to renal function and graft survival

Renal function was reduced at the time of infection in eight of the 21 patients known to have had a BK virus infection after transplantation. In three of the patients the impaired renal function was the result of acute or acute on chronic rejection unrelated to the BK virus infection and these three patients eventually had transplant nephrectomies. One other patient had progressive deterioration of renal function and transplant nephrectomy because of the recurrence of the original renal disease. In four patients, however, the reduced renal function coincided with the BK virus infection and in one patient was associated with ureteric stenosis. Renal function improved without treatment (except decreasing immunosuppression in one case) in the four patients and all had functioning renal graft at the end of the study.

Only four of the 19 patients with either a primary or secondary $\mathrm{JC}$ virus infection after transplantation also had impaired renal function at the time of the infection. In one this occurred eight days after the transplant operation and was transient. Afterwards the renal output in this patient was satisfactory for eight months until the original disease recurred. In the second patient there were no rejection episodes and renal function was good until the JC virus infection four weeks after transplant. Subsequently the function did not recover and continued to deteriorate.

Two other patients had impaired renal function five weeks and 12 weeks after the transplant operation. Both were treated with methyl prednisolone and one developed viral pericarditis with pericardial effusion. Retrospectively they were shown to have had secondary JC virus infection at this time. Renal function recovered quickly in both patients and the grafted kidneys continued to function well.

\section{Discussion}

Nearly two thirds of the patients in this study group had either a primary or a secondary infection with one or both polyomaviruses BK and JC. The polyomavirus infections were as frequent as those associated with cytomegalovirus, which are known to be common after transplantation. ${ }^{15}$ The incidence of polyomavirus infection after renal transplant was greater than that reported in 1980 by Hogan et al in the USA, where just half of the 61 patients investigated had evidence of an active infection. ${ }^{13}$

Cytological examination of the urine proved to be a useful technique in identifying polyomavirus excretors. Twenty one of the 31 patients $(68 \%)$ identified serologically as infected with BK or JC virus, or both, were found to be excreting inclusion-bearing cells, whereas none of the 11 patients with cytomegalovirus infection only were excreting these cells.

Most of the transplant patients in our study had BK virus antibodies before the transplant operation. Therefore, few were at risk of a primary infection. Nearly half of the patients, however, had no antibody to either JC virus or cytomegalovirus, and of these five $(23 \%)$ had primary infections with JC virus and six (32\%) with cytomegalovirus. Of the seropositive patients in the present study the rate of secondary infections with $\mathrm{BK}$ and $\mathrm{JC}$ viruses were $45 \%$ and $46 \%$ respectively. The rate of secondary cytomegalovirus infections in the patients was $83 \%$, an incidence similar to that found by other workers. ${ }^{15}$

An increase in antibody titre to both BK and JC viruses occurred in seven patients. In four patients the rise was observed at different times after the transplant operation, but in three patients the antibody responses were identical in timing and concentrations as can be seen in patient B (Fig. 1). Similar responses were seen in two patients reported previously. ${ }^{12}$ When the antibody responses occurred simultaneously it was difficult to assess whether both viruses were active at the same time or one response was anamnestic. One of the authors (SDG) has isolated both $\mathrm{BK}$ and JC viruses from the urine of a bone marrow transplant recipient, ${ }^{16}$ but usually only one virus is isolated. Hogan and his colleagues, ${ }^{17}$ using immunofluoresence to stain exfoliated inclusion-bearing cells, have shown both BK and JC virus antigens in the same urine sample in five patients. This technique is probably the most sensitive one for confirming mixed infections.

Most of the previous reports of polyomavirus infections in kidney transplant recipients have considered only BK virus infections and have not included serological studies with JC virus. The reported incidence of $\mathrm{BK}$ virus infections after transplantation deduced from serological observations has ranged from $12 \%$ to $38 \% .^{41318-20}$ Evidence of polyomavirus excretion confirmed by electron microscopy or by virus isolation has varied from $0 \%$ to $44 \% .^{4121821}$ The variation in these observations may be because serial sera were not examined and many of the patients studied were not investigated from before the transplant operation. Also in many instances urines may not have been taken at the peak time for virus excretion.

In the present investigation about half of the secondary polyomavirus infections occurred between four and eight weeks after transplantation compared with $71 \%$ of the cytomegalovirus infections. Late polyomavirus infections occurring eight months or 
more after operation were seen in seven of the 31 patients $(22.5 \%)$ whereas only two of the $24(8 \%)$ patients had late cytomegalovirus infections. Similarly, four of the seven primary polyomavirus infections were recognised later than three months. The primary cytomegalovirus infections occurred earlier, as reported by other workers. ${ }^{2}$ is

Clinically, there was an appreciable difference in the patients' responses to polyomavirus infections compared with cytomegalovirus. Only one of the six patients with primary polyomavirus infection had symptoms. This patient (patient B) was probably infected with both JC and BK viruses and developed only a mild pyrexia. On the other hand all six patients with primary cytomegalovirus infections were ill, three seriously, one dying of disseminated disease including pancreatitis. Most of the secondary polyomavirus infections were asymptomatic, but in three patients there were complications. One patient infected with BK virus developed ureteric obstruction and another had malaise and vomiting. A third patient infected with JC virus had pericarditis and effusion. Ureteric stenosis associated with polyomavirus infections has been reported in nine renal transplant recipients. ${ }^{3561322}$ The most recent report of three cases was from the detailed study by Hogan et al. ${ }^{13}$ The three patients reported in their paper developed ureteric stricture two, five and 10 months after transplantation. Only one patient developed the stricture during the survey period, and this patient had been infected with both BK and JC viruses. The other two patients were found to be excreting JC virus some months after the ureteric stricture was diagnosed. It is of great importance that polyomavirus associated ureteric stenosis should not be mistaken for acute rejection as any increase of immunosuppressive drugs during active polyomavirus infection may impede host response to the infection and result in an unnecessary transplant nephrectomy. The examination of urine deposits for inclusion-bearing cells would be the quickest method to detect these infections.

The only disease so far associated with JC virus has been PML. No neurological symptoms were noted in any of our patients with active JC virus infection. Pericarditis has not been reported in association with JC virus infection before. Although $\mathrm{JC}$ virus was not actually isolated from the pericardial fluid (S Clarke, personal communication) as special procedures are needed, it is interesting to speculate that JC virus infection in this patient may have affected renal function, and because immunosuppressive drugs were then increased viral pericarditis developed.

The polyomavirus infections had only a moderate effect on renal function and the outcome of the transplant operations. Reduction in renal function coincided with the polyomavirus infection in eight $(26 \%)$ of the 31 infected patients; four of these patients were infected with BK virus and four with $\mathrm{JC}$ virus. Renal function continued to deteriorate in only one of them. At the end of the study period 25 of the 31 polyomavirus infected patients $(81 \%)$ had functioning renal grafts.

We thank Mr B Pentlow and Mr $\mathrm{H}$ White for permission to study their patients and gratefully acknowledge the help of the staff in the renal transplant unit.

\section{References}

'Richardson WP, Colvin BB, Cheeseman SH, et al. Glomerulopathy associated with cytomegolavirus viraemia in renal allografts. $N$ Engl J Med 1981;305:57-63.

${ }^{2}$ Warrell MJ, Chinn I, Morris PJ, Tobin JO'H. The effects of viral infections on renal transplants and their recipients. $Q J$ Med (NS) 1980;49:219-31.

${ }^{3}$ Gardner SD, Field AM, Coleman DV, Hulme B. New human papovavirus (B.K.) isolated from urine after renal transplantation. Lancet 1971;i:1253-7.

4 Coleman DV, Gardner SD, Field AM. Human polyomavirus infection in renal allograft recipients. Br Med J 1973;iii:371-5.

${ }^{5}$ Coleman DV, MacKenzie EFD, Gardner SD, Poulding JM, Amer B, Russell WJI. Human polyomavirus (B.K.) infection and ureteric stenosis in renal allograft recipients.J Clin Pathol 1978;31:338-47.

- MacKenzie EFD, Poulding JM, Harrison PR, Amer B. Human polyomavirus (HPV) - a significant pathogen in renal transplantation. Proc Europ Dial Trans Ass 1978;15:352-60.

${ }^{7}$ Padgett BL, Walker DL, Zu Rhein GM, Eckroade RJ, Dessel $\mathrm{BH}$. Cultivation of papova-like virus from human brain with progressive multifocal leucoencephalopathy. Lancet 1971;i: $1257-60$.

${ }^{8}$ Walker DL. Progressive multifocal leucoencephalopathy: an opportunistic viral infection of the central nervous system. In: Vinken PJ, Bryum GW, eds. Handbook of clinical neurology. Amsterdam: North-Holland Publishing Company, 1978:307.

9 Jänisch von W, Gerlach H, Holzhausen H-J. Die multifokale progressive leukenzephalopathie-eine papovavirusenzephalitis. Zentralb Allg Pathol 1977;121:33-9.

${ }^{10}$ Reznik M, Halleux J, Urbain E, Mouchette R, Castermans R, Beaujean $M$. Leucoencephalopathie multifocale progressive après transplantation rénale. Acta Neurol Belg 1981;81:20514.

" Padgett BL, Walker DL. Human papovavirus JCV: Natural history, tumorigenicity and interaction with human cells in culture. In: Essex M, Todaro G, zur Hausen H, eds. Viruses in naturally occurring cancers. Cold Spring Harbor Laboratory, 1980:319-28.

${ }_{12}$ Gardner SD. Implication of papovaviruses in human diseases. In: Kurstak E, ed. Human and related viruses, part A. Comparative diagnosis of viral disease. New York: Academic Press, 1977:41-84.

${ }^{13}$ Hogan TF, Borden EC, McBain JA, Padgett BL, Walker DL. Human polyomavirus infections with $\mathrm{JC}$ virus and $\mathrm{BK}$ virus in renal transplant patients. Ann Intern Med 1980;92:373-8.

14 Coleman DV, Wolfendale MR, Daniel RA, et al. A prospective study of human polyomavirus infection in pregnancy. $J$ Infeci Dis 1980;1:142-9. 
is Ho M. Virus infections after transplantation in man. Arch Virol 1977;55: 1-24.

${ }^{16}$ Gibson PE, Gardner SD. Strain differences and some serological observations on several isolates of human polyomaviruses. In: Sever JL, Madden DL, eds. Polyomaviruses and human neurological diseases. Progress in clinical and biological research. New York: Alan R Liss Inc, 1983;105:119-32.

${ }^{17}$ Hogan TF, Padgett BL, Walker DL, Borden EC, McBain JA. Rapid detection and identification of $\mathrm{JC}$ virus and $\mathrm{BK}$ virus in human urine by using immunofluorescence microscopy. J Clin Microbiol 1980;11:178-83.

${ }^{18}$ Shah KV, Daniel RW, Ziegel RF, Murphy GP. Search for BK and SV40 virus reactivation in renal transplant recipients. Transplantation 1974;17:131-4.

${ }^{19}$ Krech U, Jung M, Price PC, Thiel G, Sege S, Reutter F. Virus infections in renal transplant recipients. $Z$ Immunforsch 1975;148:341-55.
${ }^{20}$ Billaudel S, Le Bris JM, Soulillou JP, Chippaux-Hyppolite C, Courtieu AL. Anticorps inhibant Phaemagglutination du virus BK: Brève surveillance de 52 transplantés rénaux et prévalence dans différents groupes d'age de l'ouest de la France. Ann Virol (Paris) 1981;132:337-45.

${ }^{21}$ Lecatsas G, Prozesky OW, wan Wyk J, Els HJ. Papovavirus in urine after renal transplantation. Nature 1973;241:343-4.

22 Traystman MD, Gupta PK, Shah KV, et al. Identification of viruses in the urine of renal transplant recipients by cytomorphology. Acta Cytol 1980;24:501-10.

Requests for reprints to: Dr Sylvia D Gardner, Virus Reference Laboratory, Central Public Health Laboratory, 175 Colindale Avenue, London NW9 5HT, England. 